\title{
'May I subscribe a name?’: Terms of Collaboration in 1616
}

\author{
Peter Kirwan
}

If the redating by Martin Butler and the team behind the Cambridge Edition of the Works of Ben Jonson is to be believed, then the theatrical season of 1616 began with the dancing of Ben Jonson's masque The Golden Age Restored in the Whitehall Banqueting House on January $1^{\text {st }} .{ }^{1}$ The goddess Pallas descends in order to introduce Astraea and establish the Golden Age, representing the just age of James I. In order to achieve this, she calls forth poets:

You far-famed spirits of this happy isle,

That for your sacred songs have gained the style

Of Phoebus' sons, whose notes the air aspire

Of th'old Egyptian or the Thracian lyre,

That Chaucer, Gower, Lydgate, Spenser hight,

Put on your better flames and larger light

To wait upon the age that shall your names new nourish,

Since virtue pressed shall grow, and buried arts shall flourish. (103-10)

The poets reply collectively that 'Our best of fire / Is that which Pallas doth inspire' (112-3) and join together with her to awake the masquers who represent the returned Golden Age.

In the opening days of 1616, then, Jonson (in collaboration with the designer Inigo Jones, whose designs for this masque are not extant) offers a vision of authorial collaboration. His selection of four poets laureate is significant in itself, adding the Tudor poet Edmund Spenser to a conventional grouping of the medieval poets Geoffrey Chaucer, John Gower and John Lydgate. Yet

\footnotetext{
${ }^{1}$ Martin Butler, ed., 'The Golden Age Restored' in The Cambridge Edition of the Works of Ben Jonson, edited by David Bevington, Martin Butler and Ian Donaldson (Cambridge: Cambridge UP, 2012), vol. 4, p. 447.
} 
despite identifying and naming these four poets laureate, they never speak individually. Instead, their individual voices are subordinated to a collective expression, as they speak and sing only in pairs or as a group of four. They are simultaneously remembered individually for their 'sacred songs' and required to 'put on [their] better flames and larger light' in communal service of James's Golden Age.

That the year 1616 began with an image of named authors working in collaboration is fitting, given the importance usually accorded to 1616 in established narratives of the development of dramatic authorship in England. By the end of 1616, Jonson had produced his first folio, the first major collection of works in English to feature predominantly dramatic entertainments. This book also, infamously, effaced collaboration by excluding plays written with other authors such as Eastward Ho and/or writing out the contributions of others to plays such as Sejanus, His Fall. ${ }^{2}$ It is also, perhaps, interesting to note the coincidences of a year in which several of the age's great collaborative forces died. On the date of the second performance of The Golden Age Restored, 6 January, Philip Henslowe - coordinator of a vast number of collaborative plays and the man whose papers provide the best evidence for the extent of dramatic collaboration in the period - passed away. Later in the year followed Francis Beaumont, one half of the celebrated 'Beaumont and [John] Fletcher' partnership that would be immortalized in a 1647 folio, and William Shakespeare, of whose works between a quarter and a third are now generally understood to contain the work of multiple creative agents.

It would be tempting to support a narrative in which 1616 illustrates in microcosm a shift from the collaborative milieu of early dramatic writing to the emergence of the modern author; but this is of course too neat a narrative. Wendy Wall, intervening in debates about the nature of

\footnotetext{
${ }^{2}$ The preface to the first quarto of Sejanus suggests - perhaps disingenuously - that Jonson has replaced the contributions of a 'second Pen' with 'lesse pleasing' material of his own. Ben Jonson, Sejanus his fall (London, 1605).
} 
authorship in the early modern period, argues that 'the facts about the conditions of writing and publishing still seem sketchy and ambiguous', and that the major interventions in the field have instead involved 'revisiting and arranging evidence' to suit preferred narratives of sole authorship or collaborative production; as she notes, the evidence for both narratives suggests that both were functional modes of production in the period. ${ }^{3}$ Rather than seek a neat emergence of the author in 1616 (or, indeed, 1623), Wall advocates the treatment of these narratives as 'psychologically and socially provocative fictions ... [that] prompt us to ask more questions', an approach I pursue here. ${ }^{4}$ This chapter focuses closely on the dramatic publications of 1616 to argue that print representations of dramatic authorship demonstrate a multivalent and complex picture. The terms of collaboration do not develop unilaterally, and in some cases seem to move counter to the broader historical sweep. In fact, dramatic authorship in 1616 illustrates a much wider and more diverse range of definitions of collaboration that blur, rather than reinforce, the distinctions between collaborators, authors and 'co-authors'.

\section{Print authorship}

The Database of Early English Playbooks (DEEP) lists some forty-three playbooks published in $1616 .{ }^{5}$ Twenty-seven of these are those included in Ben Jonson's Works of 1616, and another four in William Alexander's collection of closet drama, The Monarchic Tragedies. The rest, issued individually, are tabulated below.

\begin{tabular}{|l|l|l|}
\hline Authorship & Title & Title page attribution \\
\hline Anonymous & Mucedorus & 'Amplified with new Additions' \\
\hline John Marston & $\begin{array}{l}\text { Jack Drum's Entertainment (Katherine and } \\
\text { Pasquil) }\end{array}$ & 'Newly corrected' \\
\hline $\begin{array}{l}\text { Thomas } \\
\text { Dekker, }\end{array}$ & 1 The Honest Whore & 'Tho. Dekker' \\
\hline
\end{tabular}

\footnotetext{
${ }^{3}$ Wendy Wall, 'Early Modern Authorship in 2007', Shakespeare Studies 36 (2008), pp. 61-2.

4 Ibid, p. 66.

${ }^{5}$ DEEP: Database of Early English Playbooks. Ed. Alan B. Farmer and Zachary Lesser. Created 2007. Accessed 6 February 2015. <http://deep.sas.upenn.edu>.
} 


\begin{tabular}{|c|c|c|}
\hline $\begin{array}{l}\text { Thomas } \\
\text { Middleton }\end{array}$ & & \\
\hline $\begin{array}{l}\text { Christopher } \\
\text { Marlowe (and } \\
\text { others?) }\end{array}$ & Doctor Faustus (B-text) & 'Written by Ch. Marklin' \\
\hline $\begin{array}{l}\text { Edward } \\
\text { Sharpham }\end{array}$ & Cupid's Whirligig & [no information] \\
\hline $\begin{array}{l}\text { Thomas } \\
\text { Middleton }\end{array}$ & A Trick to Catch the Old One & 'By T. Midleton' \\
\hline $\begin{array}{l}\text { Lewis Machin, } \\
\text { William } \\
\text { Barkstead, } \\
\text { John Marston }\end{array}$ & The Insatiate Countess & [no information] \\
\hline $\begin{array}{l}\text { Francis } \\
\text { Beaumont, } \\
\text { John Fletcher }\end{array}$ & The Scornful Lady & $\begin{array}{l}\text { 'Written by FRA. BEAUMONT and } \\
\text { JO. FLETCHER, Gent.' }\end{array}$ \\
\hline $\begin{array}{l}\text { Anthony } \\
\text { Munday }\end{array}$ & $\begin{array}{l}\text { Chrysanaleia: The Golden Fishing, or Honor } \\
\text { of Fishmongers }\end{array}$ & $\begin{array}{l}\text { 'Deuised and written by A.M. } \\
\text { Citizen and Draper of LONDON' }\end{array}$ \\
\hline $\begin{array}{l}\text { William } \\
\text { Haughton }\end{array}$ & $\begin{array}{l}\text { Englishmen for My Money, or A Woman Will } \\
\text { Have Her Will }\end{array}$ & [no information] \\
\hline S.S. & The Honest Lawyer & 'Written by S.S.' \\
\hline $\begin{array}{l}\text { Thomas } \\
\text { Middleton }\end{array}$ & Civitatis Amor & [no information] \\
\hline
\end{tabular}

The data of these quartos can be interpreted in several ways, and Wall's caution about clear, allencompassing narratives is justified. Yet there are several points of interest. Of the twelve plays and entertainments listed here, three are understood to be collaborative and two more (Faustus and Mucedorus) are issued with new additions which postdate the original author's work. Despite this, only one title page out of twelve (The Scornful Lady) makes explicit reference to collaboration or coauthorship. Jonson's folio, which appeared in November 1616, seems to consolidate rather than create practices of attribution in which assertions of single authorship override the fine details of collaboration. Secondly, the authorial attributions are decidedly scattered. Four are attributed explicitly to known authors, although one - 'Ch. Marklin' - appears in an unfamiliar form and may well cause confusion. Two more title pages employ initials to stand for the author, with one set of initials (those on Chrysanaleia) pieced out by the civic rather than personal identity of the author, credited as 'citizen and draper of London'. The dedication inside the book identifies the author more explicitly as 'An. Mundy', just as the dedication to Cupid's Whirligig adds the initials 'E.S.' to a volume 
with no attribution on its title page. The other title pages make no mention of authors, but two of the plays are explicitly revised: Mucedorus is 'amplified with new additions' and Jack Drum's Entertainment is 'newly corrected'. The four dramas with no information on their title pages include a civil entertainment, two plays for a children's company and one for an Elizabethan adult company, but the authors are not credited.

These publications collectively demonstrate the unpredictability of print representations of early modern dramatic authorship. Collaborative plays are represented as sole-authored; soleauthored plays are represented as anonymous; authors themselves are renamed or misnamed. The inconsistency and inaccuracy of authorial attributions on dramatic title pages tends to be treated as a lack, as in Michel Foucault's identification of the impulse to 'locate the space left empty by the author's disappearance'. ${ }^{6}$ Certainly this is the project of attribution studies that seek to identify authors and categorize plays into authorial canons, and this is a project aligning neatly with the strategies of Shakespeare and Jonson's contemporaries in Ming China, who 'explicitly acknowledged that they harboured "intent"'. ${ }^{7}$ Yet where the writers of the scholar class created their song-dramas outside of their official duties, their contemporaries in England wrote within a series of overlapping systems and institutions that at times take precedence on title pages. The obvious example is the general preference for acknowledging theatre companies over authors on title pages, as for Cupid's Whirligig and Jack Drum's Entertainment (both performed by the Children of the Queen's Revels) and Mucedorus (attributed to the King's Men). This is not to deny the presence of real individual authors in writing the plays, but the culture of print prioritizes in these cases the social and collaborative milieu of performance over the circumstances of writing.

\footnotetext{
${ }^{6}$ Michel Foucault, 'What Is An Author?' (1969), trans. Josué V. Harari, in The Foucault Reader, ed. Paul Rabinow (London: Penguin, 1984), p. 115.

${ }^{7}$ See Patricia Sieber's essay in this volume.
} 
While across the early modern period there is a clear emergence of a modern author figure in print attribution, from predominantly anonymous printing in the 1570 s to the regular appearance and articulation of authorial self-assertion in the 1630s (more reminiscent of Ming dramatists, particularly in the use of prefaces to assert intent), I suggest that critics should attend to how individual books articulate their own circumstances of production, rather than lamenting 'missing' information. For this, I am inclined to stress Mark Robson's utilisation of a model of 'signature' and 'countersignature', in which 'an anonymous text might... be thought of as the "without-signature," in which the unsigned is figured in terms of an attitude towards the unknown that retains the possibility of an ethical relation' ${ }^{8}$ I find this a particularly useful way to conceptualize, for example, Thomas Middleton's Civitatis Amor (Fig. 1), a civic entertainment celebrating the investiture of James's heir, Charles, as Prince of Wales on November $4^{\text {th }} 1616$. This title page makes no mention of the authorship of the entertainment, and its anonymity arguably functions as a form of countersignature that draws attention away from authorial identity towards its authorising figure, Prince Charles himself, whose name is capitalised and set prominently on its own line. The same might be said of the title page of Chysanaleia (Fig. 2), where Anthony Munday's name is alluded to only by initials, yet his civic identity 'Citizen and Draper of London' appears in full. Here, the occasion is the admittance of a new Lord Mayor of London and the city's name, capitalised and repeated, dominates the title page. In both cases the author is speaking as representative of a larger institution, the City of London itself. The paean to the celebrated subject is legitimised not by an individual sentiment but in the capturing by a Poet of a collective voice, as in The Golden Age Restored.

[Fig 1] [Fig 2]

\footnotetext{
${ }^{8}$ Mark Robson, 'The Ethics of Anonymity' in Anonymity in Early Modern England, eds Janet Wright Starner and Barbara Howard Traister (Farnham: Ashgate, 2011), p. 170.
} 
Fig. 1 The title page of Thomas Middleton, Civitatis Amor (London, 1616). Reproduced with permission of the Huntington Library, San Marino, California.

Fig. 2 The title page of Anthony Munday, Chrysanaleia (London, 1616), attributed here to 'A.M., Citizen and Draper of LONDON'. Reproduced with permission of the Guildhall Library, City of London.

To extract the author from this social context is, I suggest, to defeat the purpose of these title pages. Unlike Wang Shizhen and other Ming dramatists whose interventions offered an individual and even oppositional voice, the dramas created here are dependent on their alignment with, and their authorship subordinate to, the formal voice of the city. This does not mean that the individual, named author is little more than a vehicle. Tracy Hill discusses the significance of Munday's reworking of patriarchal models of authorship (traditionally, the idea of 'begetting' or 'fathering' a text) through his deferral to London, referred to elsewhere as 'tender mother and Nurse'. In Chrysanaleia, Munday figures his own masculine authorship as birthed by another institution conceived of as female, The Fishmongers' Company, and speaks of himself as an orphan. Hill argues:

The Fishmongers' Company perform in a metonymic fashion the maternal role that London more generally often does for Munday. In contrast to the usual representation of the City 'Fathers', the Fishmongers are presented as a mother figure in relation to those who seek employment with them, who Munday ... likens to 'Rivers' directing themselves naturally towards 'their nursing Mother the Sea'. The master, warden and assistants of the Fishmongers, he claims here, had been entirely responsible for his birth and upbringing and even in adulthood he still places himself as dependent on their collective ability to nurture him. ${ }^{9}$

\footnotetext{
${ }^{9}$ Tracy Hill, Anthony Munday and Civic Culture (Manchester: Manchester UP, 2004), pp. 23-4.
} 
The act of authorising the text here brings into play both 'countersign' (the partial accreditation of the name 'A.M.' that draws attention to what is lacking) and 'sign' by bringing into the authorial partnership a series of social and civic institutions to which Munday considers himself beholden. The performance of authorship in this particular instance is enabled by Munday's subordination of his own name. Print authorisation signifies much more than a simple attribution (or lack of the same). It mediates modes of authorial representation that situate the text to a greater or lesser extent within the social circumstances that gave occasion to it. I suggest that what is happening in this year - and by extension, the period - is less an emergence of the modern authorising author than a complex mediation of the potential agencies of authorisation that shape texts. The trope of the begetting father figure becomes unsustainable because of the complexity of authorial relationships.

\section{Effacing collaboration}

Jonson's folio is usually considered an exemplar of the modern process of authorising a body of work, but it was not the only dramatic publication of 1616 that effaced collaboration. The 1616 quarto of Christopher Marlowe's Doctor Faustus was the first to incorporate the 'new additions' of what is commonly known as the B-text. Interestingly, however, these additions are not referred to until the next quarto of 1619 , which announces the new material. Also, the 1616 quarto proclaims itself uniquely to be written by 'Ch. Marklin'. Marklin is a fascinating figure, who in print takes sole responsibility for the entire, newly extended play of Doctor Faustus, with no reference made to previous versions or distinctions within the text. The 1619 quarto 'corrects' the authorial attribution to 'Ch. Mar' and adds notice of the new additions. Whether the 'Mar' of 1619 refers to 'Marklin' or 'Marlowe' is perhaps irrelevant, as variant spellings of names in the period are common. But both quartos present information that jars with modern understandings of authorship. 'Marklin' certainly did not write the whole of the play, and the additions announced as 'new' by the 1619 quarto are in fact at least three years old, if not older, and postdate Marlowe's death by more than two decades. Similarly, the 'new additions' to Mucedorus proclaimed on the 1616 quarto had in fact been in every 
publication of the play since 1610 , and are already in this sense at least six years 'old'. The fact that, as MacDonald Jackson and others have recently claimed, the additions to Mucedorus may well have been by the King's Men's resident playwright, William Shakespeare, goes unmentioned. ${ }^{10}$ The new text is subsumed into the old without further comment, creating yet another situation in which multiple anonymous voices contribute to the 'larger light' of the play.

The consistency here is inconsistency. Title pages are at odds with the information implied by the newly expanded texts, and the interventions of 1616 do not necessarily advance the clarification of authorship. In 1615, Beaumont and Fletcher's Cupid's Revenge had been published attributed to John Fletcher alone. In 1616, following Beaumont's death, the same company's The Scornful Lady followed with attribution to both Beaumont and Fletcher, reviving the author in fame even as his physical body died in what may be a deliberate tribute to the dramatist's passing. While collaborative authorship is correctly established in accordance with modern standards here, however, the reverse was true for the Thomas Middleton and Thomas Dekker partnership. The pair's Roaring Girl was attributed to both authors on the title page of that play's 1611 quarto, but collaboration was effaced from 1 The Honest Whore, attributed to Dekker alone when it was printed in 1616.

Attribution studies have, since the late nineteenth century, fine-tuned the details of early modern dramatic collaborations, ascertaining both the identities of authors and the precise responsibilities of those authors within dramatic texts. In the early years of the twenty-first century, this has led to the introduction of the term 'co-author' (or the elided form 'coauthor') as in the work of Brian Vickers and Jeffrey Knapp, adopting a model that prioritizes individual authorial

\footnotetext{
${ }^{10}$ See Will Sharpe in 'Authorship and Attribution' in William Shakespeare and Others: Collaborative Plays, eds Jonathan Bate and Eric Rasmussen (Basingstoke: Palgrave, 2013), pp. 710-16.
} 
responsibility and the 'correct' assignation of literary property. ${ }^{11}$ Ongoing debates in the field dispute how far such a model is appropriate to a genre that depends on the effacement of collaboration; as Jeffrey Masten argues, the role of the dramatic collaborator is to elide difference as far as possible in the service of an end product that is experienced as a unified whole. ${ }^{12}$ At stake here are a set of fundamental questions about the stake authors had in their own dramatic authorship. Did collaborating authors expect or anticipate credit for specific contributions, beyond payment? Did an author retain a sense of proprietary right over the words they had contributed, or did the unity of play take precedence? Would authors want to be individually identified within a play, and is this an appropriate critical question to be asking? David Nicol's recent work on the canon of Thomas Middleton and William Rowley takes a middle ground, arguing that critics need to be attentive to the varieties and individual manifestations of collaborative authorship. In the case of the pair's A Fair Quarrel, first performed in 1616 and printed in the following year attributed to both authors, Nicol argues

Studying A Fair Quarrel as a collaboration rather than simply as a Middleton play reveals the ways in which both authors were playing to their different strengths: paradoxically, the play's unity emerges directly from the disjointed nature of its conclusion. Simply seeing the play as constructed by a unified voice called 'Middleton-and-Rowley' is misleading: the play's ideas and structure can only be appreciated by recognizing that it was written by playwrights whose styles developed in different social contexts and whose resulting friction was creatively used in this play. ${ }^{13}$

\footnotetext{
${ }^{11}$ Brian Vickers, Shakespeare, Co-Author (Oxford: Oxford UP, 2002); Jeffrey Knapp, 'Shakespeare as Coauthor', Shakespeare Studies 36 (2008), pp. 49-59.

12 Jeffrey Masten, Textual Intercourse (Cambridge: Cambridge UP, 1997), esp. pp. 14-20.

${ }^{13}$ David Nicol, Middleton \& Rowley (Toronto: U of Toronto P, 2012), p. 118.
} 
The important distinction I would like to make here is between the acknowledgement of 'Middleton' and 'Rowley' as separate and identifiable identities within the work, and 'Middleton-and-Rowley' as a combined entity. In the case of $A$ Fair Quarrel, Nicol argues for the importance of understanding a creative conflict within the play that aligns with authorial identities. While this conflict may not have appeared so explicit to early audiences, Nicol argues that the retention of both Middleton's customary satire and Rowley's flare for romance enables a creative conflict that, if we were to assume title-page authorisations carry particular meaning, justifies the inclusion of both names on the 1617 title page. Here, the names are bound in parentheses in a way that simultaneously separates and yokes together the two authors in support of the whole. This may be coincidence, but a relatively rare acknowledgement of collaboration on a title page fits in this instance with a play that Nicol argues is dependent on the juxtaposition of two distinct voices and ideologies.

\section{[Fig .3]}

Fig. 3 The title page of Thomas Middleton and Thomas Dekker, A Faire Quarrell (London, 1617), with the authors' names bound together in parentheses. STC 17911a, Houghton Library, Harvard University.

The wider importance of Nicol's work for this period, however, is that it argues for an attuned and individual response to instances of collaboration, which in other cases might prioritize the authorial influence of actors, genres, repertories, politics and so on, while continuing to pay close attention to divisions between sections of writing. This does not contradict calls for attention to text over authorship such as those of Jeffrey Masten, and indeed Masten specifically calls for exactly the kind of study that Nicol offers. ${ }^{14}$ Nor does it deny the importance of establishing 'co-authors' and individual style, as long as this does not happen at the cost of examination of specific authorial strategy. In this period, a consensus seems to be emerging that authors can neither be disappeared

\footnotetext{
${ }^{14}$ Masten, Textual Intercourse, p. 20.
} 
entirely into a text nor considered as autonomous of the circumstances within which they write.

Reading title pages attentively may reveal much more about the text's self-conception than is usually noted, and we need to accord them this kind of nuanced attention.

\section{Conclusions}

Returning to the key text of 1616, Jonson's folio, the opening and closing contents of the volume complicate the presentation of sole authorship. The volume's first commendatory poem in the vernacular begins, simply, 'May I subscribe a name?'15 Ed. Heyward's poem proposes to subscribe a name to an individual, Jonson:

Of all I know thou onely art the man

That dares but what he can:

Yet by performance shows he can do more

Than hath bene done before,

Or will be after.

Heyward's poem offers a confident and bold statement of assertive authorship concluding with the evocative image of a monument to Jonson:

These are thy lower parts. What stands above

Who sees not yet must love,

When on the Base he reads BEN. IONSONS name,

And heares the rest from Fame.

At the beginning of Jonson's monumental book, his authorship and authority are simultaneously inscribed through the identification of a single name, presented here in block capitals. Yet within this poem there is another quill working from the first line: 'May I subscribe a name? Dares my bold quill

\footnotetext{
${ }^{15}$ Ben Jonson, The workes of Beniamin Ionson (London, 1616).
} 
/ Write that or good or ill'. The poem begins, conventionally, with Heyward musing on his own authorship before his own identity is subordinated to the volume's praise of Jonson. As with all commendatory poems, this serves a double purpose of praising the poem's addressee while also foregrounding the talent of the author. At the beginning of Jonson's sole-authored volume, therefore, a collaborator in the literary construction identifies and promotes his own influential hand.

At the other end of the 1616 volume appears the masque with which the calendar year began, The Golden Age Restored. This masque appears in two different states in different copies of the folio, both of which can be viewed on Early English Books Online, and the differences affect the words with which the masque ends. Some copies conclude the masque with a powerful speech by Astraea, who brings the masque to a celebratory conclusion in praise of the Golden Age of James.

This, this, and only such as this,

The bright Astraea's region is,

Where she would pray to live,

And in the midst of so much gold,

Unbought with grace or fear unsold,

The law to mortals give. (188-93)

This is the ending preferred by earlier editors of Jonson as giving a stronger ending to the Folio. An individual voice imposes law on mortals, arguably even articulating Jonson's own voice in bringing the masque to an ordered close. However, other copies following printing house corrections instead close with a Choir singing collectively:

To Jove, to Jove, be all the honour given,

That thankful hearts can raise from earth to heaven' (214-5) 
This ending, preferred by the Cambridge edition, reverses the direction in which the final words are spoken, replacing the sole authorial voice with collaborative acclamation. Where Astraea descends from Heaven to Earth, here the voices return 'from earth to heaven'.

The juxtaposition of these two alternate endings in different copies of the book is striking: the one coming from the 'author' of the Golden Age who has subsumed poets laureate to a broader cause and now asserts her own voice of order and control; the other a collective voice, that of a large body of singers and actors, responding to the authorial figure in joy. It is fitting, perhaps, that these two sets of voices co-exist at the end of Jonson's Folio, published in November 1616, complicating the power dynamics of authorship and vocalisation within this apparently soleauthored work even as the year drew to its close. The co-existence of the two different states of this ending serves as a fitting synecdoche for the model of authorship demonstrated throughout 1616: contingent, social, and suited to the occasions and institutions that shape the purpose of the works. 